\title{
Remote Sensing Satellites as a SOlution Towards ANTICIPATING Food AND WATER WaRS
}

\author{
DAVID Harary ${ }^{\mathrm{I}}$
}

\section{INTRODUCTION}

In December 1948, the United Nations adopted the Universal Declaration of Human Rights, which recognized the universal human right to food. Most recently in July 2010, the U.N. General Assembly adopted resolution 64/292 that recognized the human right to water as well. While food and water are of vital importance to the security of individual nations, over 700 million people lack adequate access to these basic resources. ${ }^{2}$ Alarmingly, anthropogenic induced climate change is expected to further undermine human security ${ }^{3}$ through a reduction of available food and water across particular geographic areas.

According to Lagi et al., decreased access to food and water helped stir social unrest and political instability across North Africa and the Middle East

\footnotetext{
1 David Harary is the Executive Director of the Center for Development and Strategy 501(c) (3). He completed his MSc in Sustainability Management from the University of Toronto in spring 2017 and obtained a B.A. in Economics and Geography and International Trade from the State University of New York at Buffalo in 2015. The research for this article was done in conjunction with coursework at the Munk School of Global Affairs. The author would like to thank Dr. Jon R. Lindsay for his advice in writing this article.

2 FAO, IFAD and WFP. 2015. The State of Food Insecurity in the World 2015. Meeting the 2015 international hunger targets: taking stock of uneven progress. Rome, FAO.

3 There is much discussion on the concept of human security and its definition. According to the United Nations Commission on Human Security (CHS) human security "means protecting fundamental freedoms - freedoms that are the essence of life. It means protecting people from critical (severe) and pervasive (widespread) threats and situations. It means using processes that build on people's strengths and aspirations. It means creating political, social, environmental economic, military and cultural systems that together give people the building blocks of survival, livelihood and dignity." Ogata, Sadako, and Amartya Sen. "Human security now." Commission on Human Security, Final Report, New York (2003)
} 
during the Arab Spring. ${ }^{4}$ An abundance of literature shows that although poor access to basic natural resources is not the major cause of conflict; it is a threat multiplier that can kindle conflict within or between states. ${ }^{5,6}$ However, academics, military strategists, and policymakers hotly debate the linkage between resource security and conflict, and are far from achieving broad consensus. ${ }^{7}$ Unstable social-political factors are instead generally regarded as the dominant cause behind conflict. It can therefore be said that combined with prior political instability, vulnerable regions that experience decreased food and water availability may be especially prone to an outbreak of conflict. Anticipating further escalation of instability is becoming increasingly important to intelligence agencies as they seek to prepare policymakers to avoid and/or mitigate these threats.

Stresses from climate change will likely be non-linear, unpredictable, geographically and time variant. Fortunately, new advances in remote sensing satellite technologies offer intelligence agencies a heightened ability to predict, prepare, and alarm policymakers for both short-term and long-term meteorological events.

\section{Linking Remote Sensing Satellites to Food and Water Wars}

New research continues to shed light on the intersection between environmental scarcity and conflict. However, intelligence practitioners and policymakers will most likely seek out solutions to these challenges as they worsen over the coming decades with climate change.

This article highlights the advancement of remote sensing satellites as a viable tool for intelligence agencies to predict conflict and instability. It does this by comparing the traditional intelligence gathering practices to the new capabilities remote sensing satellites grant in predicting conflict induced by resource competition or scarcity. It uses two historical case studies to examine

\footnotetext{
4 Lagi, Marco, Karla Z. Bertrand, and Yaneer Bar-Yam. "The food crises and political instability in North Africa and the Middle East." Available at SSRN 1910031 (2011).

5 Ribeiro, Wagner Costa, and Fernanda Mello Sant'Anna. "Water security and interstate conflict and cooperation." Documents d'anàlisi geogràfica 60, no. 3 (2014): 573-596.

6 Scheffran, Jürgen, Michael Brzoska, Hans Günter Brauch, P. Michael Link, and Janpeter Schilling, eds. Climate change, human security and violent conflict: challenges for societal stability. Vol. 8. Springer Science \& Business Media, 2012.

7 Floyd, Rita. "The environmental security debate and its significance for climate change." The International Spectator 43, no. 3 (2008): 51-65.
} 
the challenges intelligence agencies have with predicting such conflict. These challenges included the need for a fully-comprehensive intelligence collection methodology in anticipation for interstate conflict over shared water resources and unreliable climate models for predicting severe intrastate conflict-inducing drought. This article argues that inferior geospatial technologies in the past have not offered policymakers a widespread advantage in predicting resource conflicts. However, new technologies and methods offer governments the opportunity to do so in the future.

This article follows with a discussion on the strategic implications of the geospatial intelligence revolution as a solution towards anticipating such conflict in the coming era of climate change. It ends with an overview of the challenges and solutions intelligence agencies have in using this new information and ways they can productively integrate remote sensing satellites into their operations.

\section{Traditional TaCtics}

There are two modes by which scarce natural resources can exacerbate social unrest and worsen conflict. The first is through interstate disputes, often over riparian territory and boundaries. ${ }^{8}$ The second is domestic and is largely dependent on the availability of resources regardless of immediate actions taken by foreign entities. The former is more often resolved over a short-term basis. This is due to a greater number of actions that can be taken by policymakers to solve these issues in the short-run. For example, interstate disputes over shared water resources can easily be resolved through either diplomacy or force. Resource scarcities within countries, however, must be sustainably resolved through a more gradual shifting of economic specialization or international trade.

According to Homer-Dixon, however, interstate conflict is overall less likely to break out over scarce natural resources than intrastate conflict. ${ }^{9}$ Thus, intelligence agencies are more likely to predict state fragility, civil war, increased

\footnotetext{
8 Water resources are inextricably linked across boundaries. A country's water resources can only be sustained by inflows from upstream rills, gullies, streams, rivers, and tributaries. If any of these influxes are cut off, the total water retained by a country downstream is decreased. Toset, Hans Petter Wollebæk, Nils Petter Gleditsch, and Håvard Hegre. "Shared rivers and interstate conflict." Political Geography 19, no. 8 (2000): 971-996.

9 Homer-Dixon, Thomas F. "Environmental scarcities and violent conflict: evidence from cases." International security 19, no. 1 (1994): 5-40.
} 
authoritarianism, and migration as a result of scarce resources instead of conflicts over shared water by competing states. ${ }^{10}$ Nevertheless, this article uses case study examples of both types of conflict to provide a thorough discussion about the changing uses of geospatial intelligence as new technologies have emerged.

The following historical cases provide background to how intelligence agencies previously gained data on scarce natural resources. The first case describes a comprehensive and systematic approach to capturing this information during a time of increasing interstate tension that led to conflict. The second recounts the limitations scientists had with available technology and methods they used to anticipate intrastate fragility.

\section{Interstate Conflict}

Friction between states often arise over shared resources. Water, in particular, is a consistent source of conflict between nations for millennia. ${ }^{11}$ When critical resources are deficient, disputes between states can develop rapidly. There are countless instances in which water has been a central component of conflict and nations have used forms of espionage to negate its seizure and control. Espionage acts as a vital tool for states that wish to gain a strategic advantage in the control of these resources. The lead up to the Arab-Israeli Six-Day War is one example.

Between November 1964 and May 1967, a series of confrontations emerged along Israel's northern borders with Syria and Lebanon, an area that is especially abundant in water resources when compared to the greater Levant region. ${ }^{12}$ Called the "War over Water" these skirmishes had persisted since the ending of the 1948 Arab-Israeli War. However, it was not until January 1964 when Arab states devised plans to divert waters away from Israel - that water began to play a central role in the region's increased tensions. Syria and Lebanon, in particular, convened to cut Israel's National Water Carrier supply by $35 \% .{ }^{13}$ Numerous minor border clashes resulted. Israel reported 98 instances of encroachment by Syria between December

\footnotetext{
10 Ibid.

11 "Water Conflict Chronology." The World's Water. November 2009. Accessed November 23, 2016. http://www2.worldwater.org/conflict/index.html.

12 Kolars, John. "Water resources of the Middle East." Canadian Journal of Development Studies/ Revue canadienne d'études du développement 13, no. 4 (1992): 103-119.

13 Shapland, Greg. Rivers of discord: International water disputes in the Middle East. C. Hurst \& Co. Publishers, 1997.
} 
1962 and August $1963 .{ }^{14}$ These clashes eventually resulted in Israel's destruction of Arab heavy earth-moving machines that were used for the diversion plan. ${ }^{15}$ Despite the perception that Syria had lost interest in its plans following Israel's bombardment of bulldozers, the Syrian 1966 coup brought renewed activity to the riparian conflict. Numerous literature has since explained how these initial conflicts over water contributed to the fully-fledged Six-Day War. ${ }^{16}$

During the lead up to the war, clandestine agencies in Israel used a variety of tactics to collect key intelligence on the human geography and use of these water resources. According to Ian Black and Benny Morris in their book, Israel's Secret Wars: The Untold History of Israeli Intelligence, Israeli intelligence obtained a significant amount of data on the Golan Heights through photographic and imagery intelligence. ${ }^{17}$

Imagery intelligence obtained via air reconnaissance was often used to provide policymakers with the specific locations of major targets and points of interest. In the 1960s, imagery intelligence was still a new method of informing decision-makers of human geography phenomenon. Nearly all geospatial technologies could therefore only contribute to the development of standard products, as opposed to specialized products. Imagery collected at this time was always panchromatic, or black and white. ${ }^{18}$ These products could be used alone or combined with other layers of geographic information (such as vegetation or weather) to produce more accurate models of the environment. ${ }^{19}$

While the production and use of aerial photography was a major contributor towards Israel's intelligence collection, geographic information systems (GIS) were still in their pioneering age. ${ }^{20}$ Thus, the development of

\footnotetext{
14 Seliktar, Ofira. "Turning water into fire: The Jordan River as the hidden factor in the SixDay War.” Middle East Review of International Affairs 9, no. 2 (2005): 57-71.

15 Morris, Benny. Righteous victims: a history of the Zionist-Arab conflict, 1881-1998. Vintage, 2011.

16 Ibid. 12, 69.

17 Black, Ian, and Benny Morris. 1991. Israel's secret wars: the untold history of Israeli intelligence. London: Hamish Hamilton.

18 Standard products include maps, charts, imagery, and vector information while specialized products often combine multiple layers to create more complex and detailed products.

19 National Geospatial-Intelligence Agency. Office of Geospatial-Intelligence Management. Geospatial Intelligence (GEOINT) Basic Doctrine. Publication 1-0. 2006.

20 Coppock, J. Terry, and David W. Rhind. "The history of GIS." Geographical information systems: Principles and applications 1, no. 1 (1991): 21-43.
} 
complex GIS products was often limited by available technology and resources. Israel therefore had to rely on other methods to capture further intelligence on the extraction of water resources in the Golan Heights.

Israeli use of signals intelligence ${ }^{21}$ also contributed significantly towards the country's understanding of Syrian infrastructure and fortification. Israeli intelligence regularly eavesdropped on radio transmissions and phone calls of military and political leaders between Syria, Jordan, and Egypt. ${ }^{22}$

As strategists in Israel's defense forces required dependable data on the development of the water diversion project, intelligence collected from publicly available sources (open-source intelligence) was also used. This included the need to ascertain the project's engineering plans, diagrams, maps, as well as timely updates on Soviet influence on Syrian leaders. ${ }^{23}$ The Arab Summit of September 1964 announced plans for the water diversion project, making much of this data publicly available through open-source outlets. ${ }^{24}$ Because water availability is a major part of societal well-being, plans affecting its supply are often held in the public spotlight. The Arab states' water diversion project was no exception and Israel readily used this material.

Lastly, Israel utilized on-the-ground human intelligence to collect information on water resources in the Golan Heights. Perhaps most notably was the role Eli Cohen had in relaying a significant amount of data to Israel. ${ }^{25}$ His findings on Syrian military posts adjacent to critical resources in the Golan Heights proved to be highly influential in Israel's bombing strategy in November 1964. ${ }^{26}$ Israel utilized Cohen's human intelligence in combination with available geospatial, signals, and open-source intelligence to deploy strong responses against Syria's water diversion construction and military fortification.

It's clear that Israel's comprehensive intelligence strategy provided its military with an overwhelming advantage when war finally broke out in 1967. Had Israel not gathered information on the development and protection of new

\footnotetext{
21 Signals intelligence, on the other hand, is information gathered by the interception of communications between people.

22 Ibid. 16, 230.

23 Shlaim, Avi. The iron wall: Israel and the Arab world. Penguin UK, 2015.

24 U.S. Central Intelligence Agency. Office of Current Intelligence. Special Report: The Jordan Waters Issue. 1964.

25 Britton, Wesley. “The Eli Cohen Files." (2009).

26 Ibid.
} 
infrastructure used to divert waters, the state may not have been able to gain a strategic edge in defeating Arab militaries on the Golan Heights front. As evidenced by the Israeli example, a combination of robust geospatial, signals, open-source, and human intelligence gathering techniques contributed to Israel's strategic advantage in the control of basic resources.

\section{Intrastate Conflict}

Tension over dwindling resources within a nation's borders can also induce social unrest and even conflict in extreme cases. The responsibility of capturing data on food and water security often rests on agencies that deal with the management of such resources, instead of intelligence agencies directly. Agencies that specialize in agricultural, oceanic, atmospheric, and other environmental domains may be called upon to capture such data. Additionally, emergency management agencies may be needed in times of short-term environmental crisis.

Declining abundance of food and water resources over time can pose security risks to nations. Adverse weather patterns, such as sustained drought or flooding, can significantly influence social unrest and even political instability. An example of this is the 1980 coup d'etat in the Republic of Upper Volta (today Burkina Faso).

After gaining independence from France in 1960, Upper Volta was ruled by Maurice Yaméogo. However, in 1966, a successful coup started a long era of military rule under Lieutenant Colonel Sangoulé Lamizana. Throughout his regime, Lamizana faced increasing pressure from trade unions, political opposition groups, and perhaps most especially_drought.

Situated on the border of the Sahara Desert and the Sudanian Savanna in Africa, the Sahel has long experienced periods of severe drought and flooding. ${ }^{27}$ Between 1968-1974 and in the early 1980s, a particularly strong Sahel drought occurred. Sahelian rainfall in the late $20^{\text {th }}$ century dropped by $20-30 \% .^{28}$ It's

\footnotetext{
27 Street-Perrott, F. Alayne, J. A. Holmes, M. P. Waller, M. J. Allen, N. G. H. Barber, P. A. Fothergill, D. D. Harkness, M. Ivanovich, D. Kroon, and R. A. Perrott. "Drought and dust deposition in the West African Sahel: a 5500-year record from Kajemarum Oasis, northeastern Nigeria." The Holocene 10, no. 3 (2000): 293-302.

28 Hulme, Mike. "Climatic perspectives on Sahelian desiccation: 1973-1998." Global Environmental Change 11, no. 1 (2001): 19-29.
} 
estimated that between 1960-1980, famine in the region killed over 100,000 people. ${ }^{29}$ The drought prompted extensive action by outside countries and by $1979,70 \%$ of the government's budget had come from foreign aid. ${ }^{30}$ Additionally, the drought provoked far-reaching economic and political reforms. ${ }^{31}$ Numerous strikes broke out, which placed heavy pressure on Lamizana's government in November 1980. Finally, on November $25^{\text {th }} 1980$, Colonel Saye Zerbo led a bloodless military coup that overthrew President Lamizana.

Figure 1: Observed annual rainfall in the Sahel

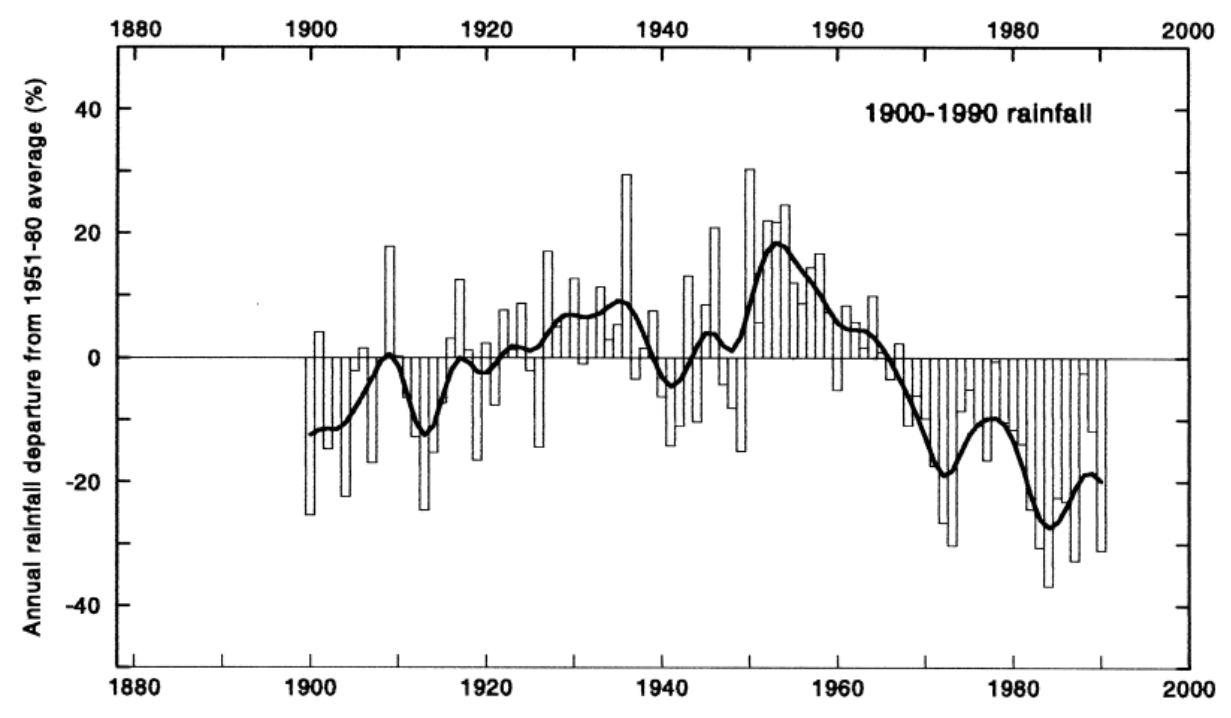

(source: Hulme, 2001) $)^{32}$

29 Copans, Jean. "The Sahelian drought: social sciences and the political economy of underdevelopment." Interpretations of calamity (1983): 83-97.

30 Rupley, Lawrence, Lamissa Bangali, and Boureima Diamitani. Historical Dictionary of Burkina Faso. Scarecrow Press, 2013.

31 Batterbury, Simon, and Andrew Warren. "The African Sahel 25 years after the great drought: assessing progress and moving towards new agendas and approaches." Global Environmental Change 11, no. 1 (2001): 1-8.

32 Ibid. 27. 
During this period, policymakers primarily used meteorological and climate models to predict and prepare for disastrous climate events. In the 1960s, scientists at the Geophysical Fluid Dynamics Laboratory in Princeton, N.J. introduced a new way of understanding earth's global climate. ${ }^{33}$ Using third generation computers, climatologists witnessed the relationships between the atmosphere, ocean, and climate. However, models between the 1960s and 1980s were still relatively primitive compared to today. Computers and satellites were not sophisticated enough to include the many variables needed to create robust and accurate projections of the earth's climate due to limitations of technology.

Hulme suggests that scientists were at fault for the region's unpreparedness for drought due to their fundamental misunderstanding of the Sahelian climate. ${ }^{34}$ Additionally, some studies conducted poor analysis of the causes and conditions of the Sahelian drought, leading to incorrect conclusions. This is exemplified by Bunting et al., whose study at the time found no evidence to expect below average rainfall in the future. ${ }^{35}$ Importantly, these false projections had significant consequences on policy makers' decision-making capabilities. ${ }^{36}$ For example, the delayed arrival of critical aid was inadequate in preventing thousands of famine-related deaths. ${ }^{37}$ Additionally, excessive overgrazing by livestock as well as construction of deep wells to tap water worsened the situation considerably. ${ }^{38}$ Policymakers may have avoided these mistakes had they been more certain of continued drought in the future.

The lack of careful planning for instances of drought or flooding can have disastrous effects on a nation's domestic stability. The 1980 Upper Volta coup is an important lesson for climatologists, meteorologists, and government

\footnotetext{
33 Schmidt, Laurie. "Satellite Observations One Key to Climate Models." Global Climate Change. April 11, 2013. Accessed November 21, 2016. http://climate.nasa.gov/news/908/ satellite-observations-one-key-to-climate-models/.

34 Ibid. 27.

35 Bunting, ArHo, M. D. Dennett, J. Elston, and J. R. Milford. "Rainfall trends in the west African Sahel." Quarterly Journal of the Royal Meteorological Society 102, no. 431 (1976): 59-64. 36 Hulme, M., and P. M. Kelly. "Exploring the linkages between climate change and desertification.” Environment 35, no. 4 (1993): 39-45.

37 Esseks, John D. "The Food Outlook for the Sahel: Regaining Self-Sufficiency or Continuing Dependence on International Aid?” Africa Today 22, no. 2 (1975): 45-56.

38 Motha, Ray. "Recommendations on Drought Monitoring by the US National Drought Policy Commission." Early Warning Systems for Drought Preparedness and Drought Management (2000): 45.
} 
agencies seeking to deliver the best available projections on water scarcity or excess precipitation. Fortunately, extensive technological shifts now enable scientists to better predict periods of resource insecurity. The development of satellite technology, in particular, is the cornerstone of the geospatial revolution. The next section examines these new advancements.

\section{Geospatial ReVolution}

Since NASA launched its first low-Earth orbital weather satellite in 1960, there has been a technological revolution in the geospatial intelligence arena. ${ }^{39}$ The success of NASA's early weather satellites, such as TIROS-1, helped spark the advancement of more sophisticated earth observation satellites. ${ }^{40}$ Most recently, innovations in satellite technology allow intelligence agencies to manage forecasting uncertainty and at times, uncover the causes behind the scarcity of natural resources. ${ }^{41}$ These innovations make it easier for scientists to develop early warning systems that more accurately predict severe weather events, such as drought. ${ }^{42}$ Additionally, these innovative technologies are allowing decisionmakers to predict instances of instability based on available food and water.

\section{New Markets}

Following George H.W. Bush's signing of the Land Remote Sensing Policy Act of 1992, private companies were allowed to use high-resolution satellite technology for the first time. ${ }^{43}$ This marked a new era for geospatial imagery as it fostered competition for newer technologies. In conjunction with emerging global positioning system (GPS) technologies; commercially available satellite imagery democratized the production, consumption, and exploitation of remote sensing and location-based data. ${ }^{44}$ The passing of this legislation was the foundation of

\footnotetext{
39 Downs, Roger M. "Coming of age in the geospatial revolution: The geographic self redefined." Human Development 57, no. 1 (2014): 35-57.

40 “TIROS.” NASA Science Beta. NASA, 22 May 2016. Web. 21 Nov. 2016.

41 Foody, Giles M., and Peter M. Atkinson, eds. Uncertainty in remote sensing and GIS. John Wiley \& Sons, 2003.

42 Kogan, Felix N. "Contribution of remote sensing to drought early warning." Early warning systems for drought preparedness and drought management (2000): 75-87.

43 Land Remote Sensing Policy Act, U.S. Code 15 (1992), \$\$ 82

44 Alderton, Matt. “The Defining Decade of GEOINT.” Trajectory Magazine, 2014. Accessed November 21, 2016. http://trajectorymagazine.com/trajectory-mag/item/1683-the-definingdecade-of-geoint.html.
} 
development for newer data gathering techniques that would subsequently be used by GEOINT practitioners.

\section{New Data}

New remote sensing satellites offer users the ability to predict and ascertain levels of precipitation, evapotranspiration, groundwater, and runoff for a given area, which were previously unmeasurable at such a large scale. ${ }^{45}$ Additionally, as these technologies have matured, their accuracy and resolution has increased substantially.

Remote sensing satellites have been in use since the 1960s and 1970s to record the Earth's surface in different portions of the electro-magnetic spectrum. As the longest-running enterprise for acquisition of satellite imagery of Earth, the Landsat program in particular revolutionized the kind of data that is used for agriculture, cartography, geology, forestry, hydrology, and surveillance. Many consecutive satellite programs have broadened the variety of data that can be used for resource security needs. These programs are more often operated by agencies focused on the environment, as opposed to intelligence agencies directly. In the U.S., these include NASA, the National Oceanic and Atmospheric Administration (NOAA), and the U.S. Geological Survey (USGS). However, intelligence agencies often find these data more useful as the linkages between resource security and conflict become better understood. ${ }^{46}$ The primary U.S. GEOINT agency, the National Geospatial-Intelligence Agency (NGA), has thus partnered with these agencies to develop more comprehensive products for intelligence personnel and decision-makers.

\section{New Products}

Newer data has sparked the creation of more interactive and intelligible GEOINT products. Specialized GEOINT products use standard products as a

\footnotetext{
45 Remote sensing acquires information about objects or phenomenon of the earth from a distance, often via aircraft or satellites. Sensors measure the amount of electromagnetic radiation (EMR) emitted from objects or a geographic area. Data is then extracted using mathematically and statistically-based algorithms.

46 Fingar, Thomas. National intelligence assessment on the national security implications of global climate change to 2030: Statement for the record of Dr. Thomas Fingar. US House of Representatives, 2008.
} 
foundation but have added capabilities. ${ }^{47}$ These products are recently developed by combining data from multiple sources and utilize a variety of intelligence gathering methods. The development of new remote sensing technologies has allowed these products' potential to grow, particularly through increasing satellite capabilities. A key component of this process has been the utilization of a fourth dimension time. This has provided intelligence agencies with the ability to ascertain context and changes over multiple dates, as well as tracking functionality to create dynamic, interactive products. Better products that describe the earth's environment can allow policymakers to more easily understand and predict instances of resource insecurity.

\section{New Methods}

In order to ensure that GEOINT products are comprehensive, agencies typically incorporate a rigorous method of intelligence analysis. Over the last decade, the NGA modified a commonly used analytic methodology (Joint Intelligence Preparation of the Battlespace or JIPB) so that products can be used for nonmilitary intelligence problems. ${ }^{10}$ The new Geospatial Intelligence Preparation of the Environment process enables both military as well as non-battlefield decisionmakers to predict or respond to national security special events, disaster relief, noncombatant evacuations, and to specific national security requirements. ${ }^{10}$ The NGA's revision of JIPB is especially important given predicted increasing civilian and non-traditional threats as a result of climate change. ${ }^{48}$

\section{STRATEGIC IMPLiCATIONS}

Innovations in satellite technologies and their use have a wide array of strategic implications for both GEOINT practitioners as well as decision-makers. However, there are specific implications for the purposes of gathering intelligence on food and water resources and their relation to the political stability of nations. This section provides a brief synopsis of the meaning behind the GEOINT

\footnotetext{
47 United States. Joint Force Command. Geospatial Intelligence in Joint Operations. N.p., 14 July 2014. Web. 22 Nov. 2016.

48 Femia, Francesco, and Caitlin Werrell. UPDATE: Climate and Security 101: Why the U.S. National Security Establishment Takes Climate Change Seriously. Report no. 23. The Center for Climate and Security. February 26, 2014. Accessed November 21, 2016. https:// climateandsecurity.files.wordpress.com/2012/04/update_climate-and-security-101_why-the-u-snational-security-establishment-takes-climate-change-seriously_briefer-232.pdf.
} 
revolution for the security of food and water.

\section{Food Security}

New remote sensing satellite technologies have the ability to provide greater insight on agricultural productivity. A wide range of data can be obtained via remote sensing applications in site specific crop management (SSCM). These data can allow users to ascertain climate, soil, weed, and disease conditions for a given area of agricultural land. ${ }^{49}$ This information can then be used for either management or prediction purposes. In the context of GEOINT, practitioners can use this information to produce maps that predict overall crop yield. Thus, food availability for communities reliant on these resources can be estimated. Decision-makers can also make use of these estimations by creating reactive policies that mitigate food shortages in these areas.

NASA's January 2015 launch of the Soil Moisture Active Passive (SMAP) mission satellite is an example of these new capabilities. In addition to offering better predictions of weather, climate, drought, and flooding; SMAP will improve crop yield forecasts throughout the world. ${ }^{50}$ These improved seasonal soil moisture forecasts will also make famine early warning systems more robust, thereby providing critical information for intelligence agencies focused on political instability as a result of food insecurity.

Perhaps most important is the use of these satellites in regions where SSCM capabilities are poor. SSCM via satellites alleviates the need for travel, equipment hauling, and considerable logistics planning. Thus, compared to conventional sources; satellite data is often very timely, reliable, and inexpensive to acquire globally. ${ }^{51}$ Satellite imagery in areas with few technological resources are critical because they provide visual data in places otherwise limited to such information.

\footnotetext{
49 Atherton, B. C., M_T Morgan, S. A. Shearer, T. S. Stombaugh, and A. D. Ward. "Sitespecific farming: A perspective on information needs, benefits and limitations." Journal of soil and water conservation 54, no. 2 (1999): 455-461.

50 Entekhabi, Dara, Eni G. Njoku, Peggy E. O’Neill, Kent H. Kellogg, Wade T. Crow, Wendy N. Edelstein, Jared K. Entin et al. "The soil moisture active passive (SMAP) mission." Proceedings of the IEEE 98, no. 5 (2010): 704-716.

51 Lindsey, Rebecca, and Curt Reynolds. "Just Add Water: A Modern Agricultural Revolution in the Fertile Crescent." Earth Observatory. September 15, 2003. Accessed November 25, 2016. http://earthobservatory.nasa.gov/Features/HarranPlains/.
} 


\section{Water Security}

The ability to determine levels of water security can also be bolstered by the use of new remote sensing satellites. Earth observation satellites can be used to monitor and predict groundwater supplies, evapotranspiration, precipitation, flooding, drought, and atmospheric changes in a given region. Similar to the application of SSCM, water availability for communities can be estimated based on this data.

Nations prone to increased water scarcity in the coming decades are investing in these technologies to better manage and prepare for drought and instability. Egypt, for example, launched its EgyptSat 2 satellite in April 2014 to monitor the country's water security and the Grand Ethiopian Renaissance Dam, among other mission objectives. ${ }^{52}$ This occurred amid disputes with Ethiopia over construction of the dam..$^{53}$ Since its launch, the satellite has captured intelligence on Ethiopia's intentions for the dam. ${ }^{54}$ It's likely for more remote sensing satellites to be launched in regions already sensitive to water scarcity.

\section{Utilization for Predicting Conflict}

Unlike agricultural systems, the water boundaries are often difficult to define. Agricultural land can be divided more easily than bodies of water; as such boundaries over water are often highly contested between states. ${ }^{55}$ Interstate disputes are therefore more likely to breakout over scarce water than food. This implies that in order to predict conflict between nation states, intelligence agencies should observe riparian boundaries more closely than agricultural productivity as a source for tension. Thus, new remote sensing satellites can be best utilized by intelligence agencies to predict intrastate conflict resulting from food and water insecurity.

The geospatial revolution has enabled intelligence agencies to easily capture data on scarce natural resources. Compared to prior methods, remote sensing

\footnotetext{
52 Aman, Ayah, and Kamal Fayad. "Egyptian Satellite Will Monitor Water Security, Renaissance Dam.” Al-Monitor, May 8, 2014. Accessed November 26, 2016. http://www.al-monitor.com/ pulse/originals/2014/05/egypt-satellite-launch-space-program-renaissance-dam.html.

53 Hussein, Walaa, and Joelle El-Khoury. "Water Wars Intensify between Egypt, Ethiopia." AlMonitor, March 3, 2016. Accessed November 26, 2016. http://www.al-monitor.com/pulse/ originals/2016/03/egypt-ethiopia-renaissance-dam-water-storage-nile-dispute.html.

54 Ibid.

55 Cole, George M. Water boundaries. Vol. 4. John Wiley \& Sons, 1997.
} 
satellites offer both added capability and accuracy towards predicting resource insecurity. This has also alleviated the need for comprehensive operations, such as the systematic use of multiple forms of intelligence gathering in order to ascertain whether scarce resources pose risk towards nations. The next section reviews the application of new remote sensing satellites in modern-day conflict situations. It includes an overview of the remaining challenges intelligence agencies face and the solutions they need in order to alleviate them.

\section{Applications}

The greater use of newer GEOINT methods and technologies has been matched by increased threats on food and water resources. The 2014 Fifth Assessment Report (AR5) of the United Nations Intergovernmental Panel on Climate Change (IPCC) found a wide-range of consequences for human societies as a result of increasing vulnerabilities to the world's freshwater resources from climate change. ${ }^{56}$ The AR5 found that climate change will likely increase the frequency of both meteorological droughts (less rainfall) and agricultural droughts (less soil moisture) in regions that are already dry. Additionally, the AR5 found the likelihood for increased competition over water among agriculture, ecosystems, settlements, industry, and energy production in most dry regions throughout the globe. ${ }^{57}$ This will likely negatively affect regional food and water security.

Homer-Dixon's 1994 study suggests that internal conflict resulting from environmental scarcity can lead to either the fragmentation of states, which could drive large out-migrations, or it could lead to increased authoritarianism, which could ignite international conflict. ${ }^{58}$ The former was seen in the case of the Arab Spring that started in December 2010.

\footnotetext{
56 Barros, V. R., C. B. Field, D. J. Dokke, M. D. Mastrandrea, K. J. Mach, T. E. Bilir, M. Chatterjee et al. "Climate Change 2014: Impacts, Adaptation, and Vulnerability. Part B: Regional Aspects. Contribution of Working Group II to the Fifth Assessment Report of the Intergovernmental Panel on Climate Change." (2014).

57 Ibid.

58 Ibid. 8 .
} 


\section{Case Study: Climate Change and the Arab Spring}

Over the last several years, evidence has mounted that climate change was a major threat multiplier in the breakout of revolts across the Arab world..$^{59}$ A 2012 report by Lieutenant Colonel El Hassane Aissa of the Moroccan Army found many of the primary causes of the Arab Spring to be within the socio-political arena. ${ }^{60}$ Potential causes included the lack of economic sovereignty, political disaffection, provocation of social media, and poor education. However, Aissa also noted the significant role resource insecurity had with the sparking of mass protests and revolts.

While numerous studies have determined the causes behind the Arab Spring, President Barack Obama was disappointed with the intelligence community's (IC) failure to anticipate instability before it occurred. ${ }^{61}$ This may have been partially due to numerous issues with the IC's access and use of information related to resource security and its relationship with climate change. Major tools that estimate state fragility and climate vulnerability detected an improving overall trend in the five years prior to the uprisings in Syria and Egypt. ${ }^{62}$ This is despite measurable climate events that induced greater food and water insecurity, which created the conditions that contributed to instability in the region. ${ }^{63}$ There are clear issues with available tools that predict state fragility as a consequence of resource insecurity. Several of these challenges can be identified with respect to the use of remote sensing satellites by intelligence agencies.

\footnotetext{
59 Werrell, Caitlin E., Francesco Femia, and Anne-Marie Slaughter. "A Climate and Security Correlations Series." Center for American Progress. February 28, 2013. Accessed November 24, 2016. https://www.americanprogress.org/issues/security/reports/2013/02/28/54579/the-arabspring-and-climate-change/.

60 Aissa, El Hassane. The Arab Spring: causes, consequences, and implications. U.S. Army War College. Carlisle, PA. March 2012.

61 Morell, Michael. The Great War of Our Time: The CIA's Fight Against Terrorism--from Al Qa'ida to ISIS. Hachette UK, 2015.

62 Werrell, Caitlin E., Francesco Femia, and Troy Sternberg. "Did we see it coming?: State fragility, climate vulnerability, and the uprisings in Syria and Egypt." SAIS review of international affairs 35, no. 1 (2015): 29-46.

63 Ibid.
} 
Figure 2: FAO Food Price Index and 'food riots' in North Africa and the Middle East. The overall death toll is reported in parentheses

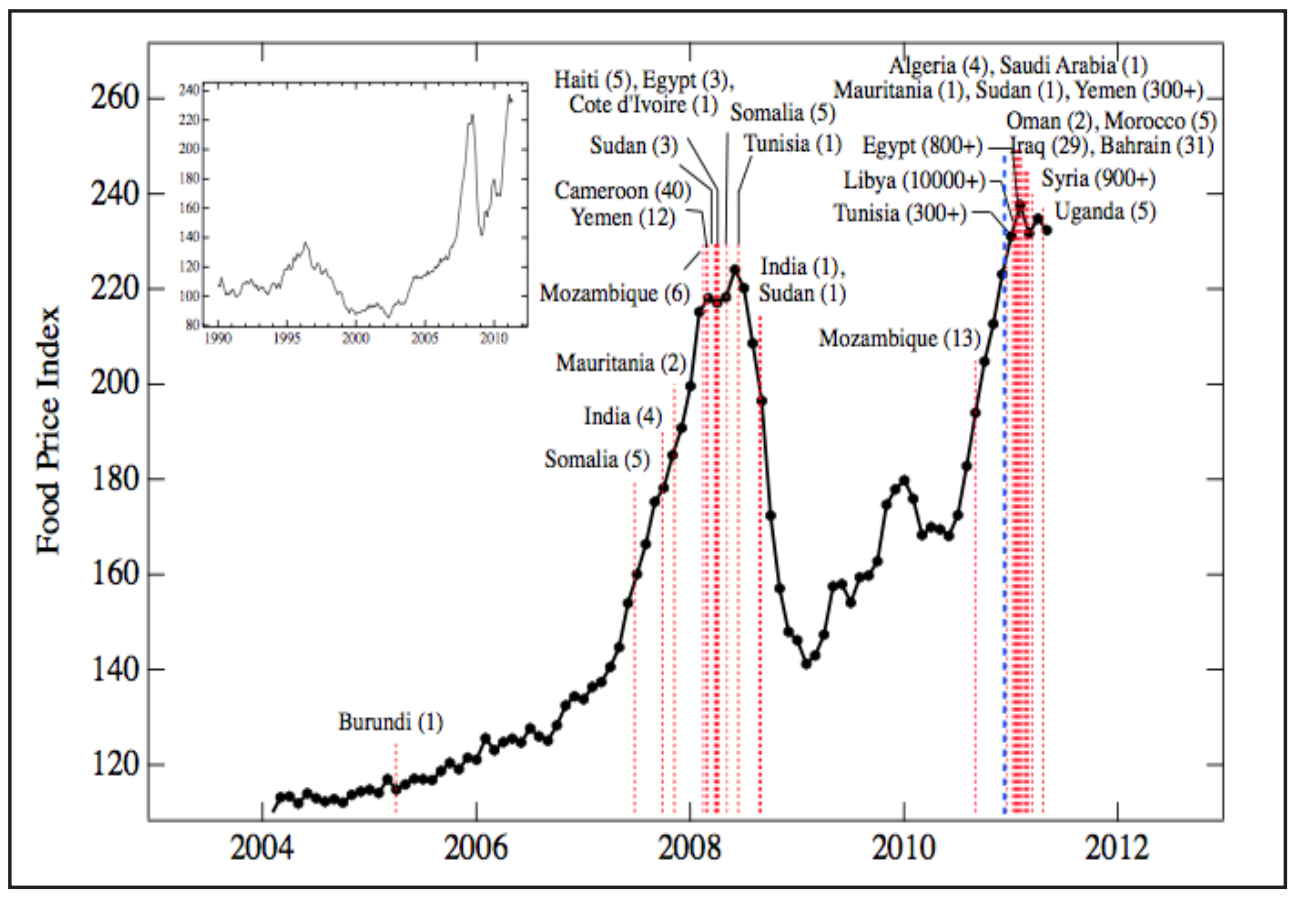

(source: Lagi et al.) ${ }^{64}$

\section{Challenges}

According to Kaplan, a lack of information sharing as well as an absence of a central authority on the intersection between resource security, climate, and political instability has hindered the IC's analytic capabilities. ${ }^{65}$ While the USGS Civil Applications Committee (CAC) forms a bridge between the IC and U.S. scientific agencies, Kaplan called for greater coordination between these

\footnotetext{
64 Ibid. 3.

65 Kaplan, Melanie. "A Signal from the Noise." Trajectory Magazine, 2015. Accessed November 24, 2016. http://trajectorymagazine.com/trajectory-mag/item/2029-a-signal-fromthe-noise.html.
} 
organizations. This is exemplified by the CIA's shut down of its Center on Climate Change and National Security in 2012 as well as its most recent shut down of its core climate research program, Measurements of Earth Data for Environmental Analysis (MEDEA) in 2015.66

In addition to the bureaucratic challenges facing GEOINT practitioners, there are also issues with scientists' ability to predict exactly when and where periods of severe climatic events occur. Research reports, such as the AR5, instead give insight on the overall trends the earth's climate and weather may bring to particular regions. Additionally, understanding how specific communities would adapt to such environmental shifts is perhaps just as important, yet difficult to ascertain. From an applications perspective, these challenges may partially explain the IC's failure to predict food and water insecurity in Arab states, and therefore the Arab Spring at-large.

\section{Solutions}

As the GEOINT revolution has brought new organizations, data, products, and methods to the table; intelligence agencies are more able to predict periods of instability as a result of scarce resources. While their capabilities increase, it is yet to be seen whether these new tools have been effectively put to use in predicting and quelling social unrest from climate change. It's therefore critical for state civilian agencies, intelligence practitioners, and militaries to work more collaboratively by utilizing the full potential of remote sensing satellite technologies and techniques.

In recognition of these needs, the NGA has launched a variety of initiatives to work more closely with civilian scientists focused on the security of natural resources. This included a $\$ 20$ million multi-year research grant to Arizona State University for the purposes of studying climate change and anticipatory analytics. ${ }^{67}$ However, empirical research on the use of remote sensing satellites by intelligence agencies is needed. Additionally, examining what the best practices are for intelligence agencies can help improve anticipatory strategies for dealing with outbreaks of political instability, state fragility, and conflict.

\footnotetext{
66 Plautz, Jason. "CIA Shuts Down Climate Research Program.” The Atlantic, May 21, 2015. Accessed November 24, 2016. http://www.theatlantic.com/politics/archive/2015/05/cia-shutsdown-climate-research-program/452502/.

67 National Geospatial-Intelligence Agency. "NGA, Arizona State University to Study Climate Change, Anticipatory Analytics with \$20 Million Research Grant.” News release, 2014. NGA. Accessed November 24, 2016. https://www.nga.mil/MediaRoom/News/Pages/ASUGrant.aspx.
} 


\section{Conclusion}

This article highlights remote sensing satellite technologies as a new method in gathering intelligence on critical food and water resources. As conflicts over these resources continue to breakout, the use of these technologies will become more recognized and important for intelligence agencies. Climate change will further limit the availability of these resources and will therefore place greater stress on communities. Anticipating these effects will be necessary as food and water insecurity are significant threat multipliers to the stability of nations. Innovations in remote sensing satellites offers GEOINT practitioners an enhanced capability to fulfill these needs.

While remote sensing satellites offer intelligence agencies enhanced capabilities than before, it has yet to be seen whether they have been successful in predicting instability as a result of scarce food or water resources. Empirical research on the efficacy of remote sensing satellites to anticipate state fragility and conflict is desired. Additionally, further investigation on the connections and gaps between the IC and civilian agencies is needed in order to determine best practices and offer further recommendations. Policymakers would find such research especially useful as it would allow them to determine what programs are worthy of further investments in order to bolster national security and global stability. 


\section{BiblograPHY}

Aissa, El Hassane. The Arab Spring: causes, consequences, and implications. U.S. Army War College. Carlisle, PA. March 2012.

Alderton, Matt. “The Defining Decade of GEOINT.” Trajectory Magazine, 2014. Accessed November 21, 2016. http://trajectorymagazine.com/trajectory$\mathrm{mag} /$ item/1683-the-defining-decade-of-geoint.html.

Aman, Ayah, and Kamal Fayad. "Egyptian Satellite Will Monitor Water Security, Renaissance Dam.” Al-Monitor, May 8, 2014. Accessed November 26, 2016. http://www.al-monitor.com/pulse/originals/2014/05/egyptsatellite-launch-space-program-renaissance-dam.html.

Atherton, B. C., M_T Morgan, S. A. Shearer, T. S. Stombaugh, and A. D. Ward. "Site-specific farming: A perspective on information needs, benefits and limitations." Journal of soil and water conservation 54, no. 2 (1999): 455461.

Barros, V. R., C. B. Field, D. J. Dokke, M. D. Mastrandrea, K. J. Mach, T. E. Bilir, M. Chatterjee et al. "Climate Change 2014: Impacts, Adaptation, and Vulnerability. Part B: Regional Aspects. Contribution of Working Group II to the Fifth Assessment Report of the Intergovernmental Panel on Climate Change.” (2014).

Batterbury, Simon, and Andrew Warren. "The African Sahel 25 years after the great drought: assessing progress and moving towards new agendas and approaches." Global Environmental Change 11, no. 1 (2001): 1-8.

Black, Ian, and Benny Morris. 1991. Israel's secret wars: the untold history of Israeli intelligence. London: Hamish Hamilton.

Britton, Wesley. “The Eli Cohen Files.” (2009).

Bunting, ArHo, M. D. Dennett, J. Elston, and J. R. Milford. "Rainfall trends in the west African Sahel." Quarterly Journal of the Royal Meteorological Society 102, no. 431 (1976): 59-64.

Cole, George M. Water boundaries. Vol. 4. John Wiley \& Sons, 1997. 
Copans, Jean. "The Sahelian drought: social sciences and the political economy of underdevelopment." Interpretations of calamity (1983): 83-97.

Coppock, J. Terry, and David W. Rhind. "The history of GIS.” Geographical information systems: Principles and applications 1, no. 1 (1991): 21-43.

Downs, Roger M. "Coming of age in the geospatial revolution: The geographic self re-defined." Human Development 57, no. 1 (2014): 35-57.

Entekhabi, Dara, Eni G. Njoku, Peggy E. O’Neill, Kent H. Kellogg, Wade T. Crow, Wendy N. Edelstein, Jared K. Entin et al. "The soil moisture active passive (SMAP) mission.” Proceedings of the IEEE 98, no. 5 (2010): 704716.

Esseks, John D. "The Food Outlook for the Sahel: Regaining Self-Sufficiency or Continuing Dependence on International Aid?.” Africa Today 22, no. 2 (1975): 45-56.

FAO, IFAD and WFP. 2015. The State of Food Insecurity in the World 2015. Meeting the 2015 international hunger targets: taking stock of uneven progress. Rome, FAO.

Femia, Francesco, and Caitlin Werrell. UPDATE: Climate and Security 101: Why the U.S. National Security Establishment Takes Climate Change Seriously. Report no. 23. The Center for Climate and Security. February 26, 2014. Accessed November 21, 2016. https://climateandsecurity. files.wordpress.com/2012/04/update_climate-and-security-101_whythe-u-s-national-security-establishment-takes-climate-change-seriously_ briefer-232.pdf.

Fingar, Thomas. National intelligence assessment on the national security implications of global climate change to 2030: Statement for the record of Dr. Thomas Fingar. US House of Representatives, 2008.

Floyd, Rita. "The environmental security debate and its significance for climate change." The International Spectator 43, no. 3 (2008): 51-65. 
Foody, Giles M., and Peter M. Atkinson, eds. Uncertainty in remote sensing and GIS. John Wiley \& Sons, 2003.

Homer-Dixon, Thomas F. "Environmental scarcities and violent conflict: evidence from cases." International security 19, no. 1 (1994): 5-40.

Hulme, Mike. “Climatic perspectives on Sahelian desiccation: 1973-1998.” Global Environmental Change 11, no. 1 (2001): 19-29.

Hulme, M., and P. M. Kelly. "Exploring the linkages between climate change and desertification.” Environment 35, no. 4 (1993): 39-45.

Hussein, Walaa, and Joelle El-Khoury. "Water Wars Intensify between Egypt, Ethiopia." Al-Monitor, March 3, 2016. Accessed November 26, 2016. http://www.al-monitor.com/pulse/originals/2016/03/egypt-ethiopiarenaissance-dam-water-storage-nile-dispute.html.

Kaplan, Melanie. "A Signal from the Noise.” Trajectory Magazine, 2015. Accessed November 24, 2016. http://trajectorymagazine.com/trajectory-mag/ item/2029-a-signal-from-the-noise.html.

Kogan, Felix N. "Contribution of remote sensing to drought early warning." Early warning systems for drought preparedness and drought management (2000): 75-87.

Kolars, John. "Water resources of the Middle East." Canadian Journal of Development Studies/Revue canadienne d'études du développement 13, no. 4 (1992): 103-119.

Lagi, Marco, Karla Z. Bertrand, and Yaneer Bar-Yam. "The food crises and political instability in North Africa and the Middle East." Available at SSRN 1910031 (2011).

Land Remote Sensing Policy Act, U.S. Code 15 (1992), $\$ \$ 82$.

Lindsey, Rebecca, and Curt Reynolds. "Just Add Water: A Modern Agricultural Revolution in the Fertile Crescent." Earth Observatory. September 15, 2003. Accessed November 25, 2016. http://earthobservatory.nasa.gov/ 
Features/HarranPlains/.

Morell, Michael. The Great War of Our Time: The CIA's Fight Against Terrorism-from Al Qa'ida to ISIS. Hachette UK, 2015.

Morris, Benny. Righteous victims: a history of the Zionist-Arab conflict, 1881-1998. Vintage, 2011.

Motha, Ray. "Recommendations on Drought Monitoring by the US National Drought Policy Commission." Early Warning Systems for Drought Preparedness and Drought Management (2000): 45.

National Geospatial-Intelligence Agency. "NGA, Arizona State University to Study Climate Change, Anticipatory Analytics with \$20 Million Research Grant.” News release, 2014. NGA. Accessed November 24, 2016. https://www.nga.mil/MediaRoom/News/Pages/ASUGrant.aspx.

National Geospatial-Intelligence Agency. Office of Geospatial-Intelligence Management. Geospatial Intelligence (GEOINT) Basic Doctrine. Publication 1-0. 2006.

Plautz, Jason. "CIA Shuts Down Climate Research Program." The Atlantic, May 21, 2015. Accessed November 24, 2016. http://www.theatlantic. com/politics/archive/2015/05/cia-shuts-down-climate-researchprogram/452502/.

Ribeiro, Wagner Costa, and Fernanda Mello Sant'Anna. "Water security and interstate conflict and cooperation." Documents d'anàlisi geogràfica 60, no. 3 (2014): 573-596.

Rupley, Lawrence, Lamissa Bangali, and Boureima Diamitani. Historical Dictionary of Burkina Faso. Scarecrow Press, 2013.

Scheffran, Jürgen, Michael Brzoska, Hans Günter Brauch, P. Michael Link, and Janpeter Schilling, eds. Climate change, human security and violent conflict: challenges for societal stability. Vol. 8. Springer Science \& Business Media, 2012. 
Schmidt, Laurie. "Satellite Observations One Key to Climate Models." Global Climate Change. April 11, 2013. Accessed November 21, 2016. http:// climate.nasa.gov/news/908/satellite-observations-one-key-to-climatemodels/.

Seliktar, Ofira. "Turning water into fire: The Jordan River as the hidden factor in the Six-Day War." Middle East Review of International Affairs 9, no. 2 (2005): 57-71.

Shapland, Greg. Rivers of discord: International water disputes in the Middle East. C. Hurst \& Co. Publishers, 1997.

Shlaim, Avi. The iron wall: Israel and the Arab world. Penguin UK, 2015.

Street-Perrott, F. Alayne, J. A. Holmes, M. P. Waller, M. J. Allen, N. G. H. Barber, P. A. Fothergill, D. D. Harkness, M. Ivanovich, D. Kroon, and R. A. Perrott. "Drought and dust deposition in the West African Sahel: a 5500-year record from Kajemarum Oasis, northeastern Nigeria." The Holocene 10, no. 3 (2000): 293-302.

“TIROS.” NASA Science Beta. NASA, 22 May 2016. Web. 21 Nov. 2016.

Toset, Hans Petter Wollebæk, Nils Petter Gleditsch, and Håvard Hegre. "Shared rivers and interstate conflict." Political Geography 19, no. 8 (2000): 971996.

U.S. Central Intelligence Agency. Office of Current Intelligence. Special Report: The Jordan Waters Issue. 1964.

United States Joint Force Command. Geospatial Intelligence in Joint Operations. N.p., 14 July 2014. Web. 22 Nov. 2016.

"Water Conflict Chronology." The World's Water. November 2009. Accessed November 23, 2016. http://www2.worldwater.org/conflict/index.html.

Werrell, Caitlin E., Francesco Femia, and Anne-Marie Slaughter. "A Climate and Security Correlations Series." Center for American Progress. February 28, 2013. Accessed November 24, 2016. https://www.americanprogress.org/ 
issues/security/reports/2013/02/28/54579/the-arab-spring-and-climatechange/.

Werrell, Caitlin E., Francesco Femia, and Troy Sternberg. "Did we see it coming?: State fragility, climate vulnerability, and the uprisings in Syria and Egypt." SAIS review of international affairs 35, no. 1 (2015): 29-46. 